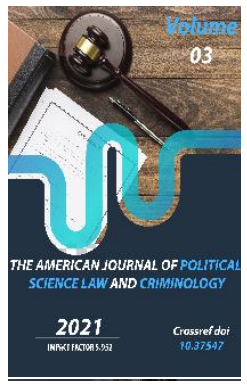

Copyright: Original content from this work may be used under the terms of the creative commons attributes 4.0 licence.

\section{Considerations For The Prevention Of Crimes Against The Sexual Integrity Of Minors}

\author{
Salomat Saparovna Niyozova \\ Against Corruption Of Tashkent State University Of Law, Uzbekistan \\ Dr. Ravinder Kumar \\ Associate Professor Law Niilm University Kaithal, India
}

DSc In Law, Acting Professor Of The Department Of Criminal Law, Criminology And Fight

\title{
ABSTRACT
}

This article provides considerations on the prevention of sexual offenses against minors. The article also covers the activities of the subjects of prevention of crimes against the sexual integrity of minors and provides relevant suggestions and recommendations.

In addition, this article analyzes the normative legal acts of the Republic of Uzbekistan. In addition, this article examines the importance of the family in the prevention of crimes against the sexual integrity and sexual freedom of minors, especially the high incidence of such crimes within the family, which means that important measures need to be developed in this area.

This article discusses the registration of unhealthy families and the establishment of constant public control over them, the identification of morally unhealthy parents with various behavioral disorders, their upbringing through community influence, and the behavior of parents whose disorders may adversely affect their minor children. Opinions were expressed on the need for prevention and appropriate recommendations for its prevention.

\section{KEYWORDS}

Minors, crimes, punishment, liability, prevention, sexual freedom, sexual integrity, aggression, measures. 


\section{INTRODUCTION}

It is known that most of the reforms carried out in recent years in our country are aimed at protecting human rights, enhancing its place in society and in the state, protecting it from various aggressions, creating opportunities for the exercise of their rights and interests.

The future of any society and state directly depends on the assessment of the moral perceptions and behavior of the population, as well as their moral health. The moral views of a society are encompassed by the system of duties and honors, justice and injustice, good and evil, traditions and customs, ideas and rules of conduct and norms that prevail among a particular community, as well as the individual morality of the individual. assessed as an object of criminal protection.

Criminal-legal protection of generally accepted norms of morality is protected by the norms of various sections and chapters of the Criminal Code (crimes against the person, crimes against public order, etc.). However, the main task of these norms is to protect the moral health and inviolability of the individual (representing the interests of the individual) and the population living in a particular area.

Based on this, the Action Strategy for the five priority areas of development of the Republic of Uzbekistan for 2017-2021 sets tasks such as the increasing the effectiveness of coordination of activities in the fight against crime and in the prevention of a crime3.

Q.R.Abdurasulova, O.Zokirova. Criminology. Training manual. - T .: TDYuI, 2003. - P. 28-29.
Indeed, the protection of the person from criminal aggression, the problem of combating crime, can be solved only by strict compliance with applicable laws and when the crime is considered the most negative situation in the life of society. Our government pays special attention to this issue and promotes the fight against crime in all documents. One of the main tasks of our state is to strengthen and reinforce the rule of law in society, to further improve and increase the efficiency of the work carried out to increase the responsibility of the judiciary, prosecutors, justice and law enforcement agencies in this regard.

Today, one of the most dangerous crimes, the actions that must be addressed and are important for society and directed against the person, is violating sexual freedom and inviolability, and the actions against morality. This, in turn, indicates the need to further improve and increase the effectiveness of the mechanism of criminal prosecution for this crime.

Prevention of crimes against the sexual integrity and freedom of minors is one of the important tasks aimed at educating them today as a comprehensively developed generation of our country.

It should be noted that the prevention of sexual offenses against minors, as well as the prevention of any crime, must be scientifically based and legal'. 
The issue of crime prevention has long been of interest to scientists. Reflections on this can also be found in the works of the ancient Greeks, Plato and Aristotle. According to Plato, the law should discourage people from committing crimes. Aristotle, on the other hand, emphasized the importance of fighting immoral customs and habits. Later, other thinkers also addressed this issue. Montesquieu, Beccaria, Voltaire, AN Radishchev showed that the supreme power can direct the actions of citizens to the rule of law through means of prohibition, encouragement and warning ${ }^{2}$.

When taking preventive measures to combat sexual crimes and offenses, it is necessary to distinguish two groups of persons to whom such measures are applied: persons with previous convictions and those whose subjective characteristics do not preclude their possibility of committing offenses.

As for the first group, the courts are obliged to determine the sum of the circumstances that led to the commission of the crime on the basis of the principle of subjective guilt.

This criterion should include all the subjective determinants of the crime (interests, motives, etc.) that led to the formation of criminal intent, as well as the circumstances and factors that influenced the commission of the crime.

Once the court has identified the real motives, it should develop a strategy of preventive work that is carried out with the individual who committed the crime.

In this regard, one thing should be taken into

\footnotetext{
2 A.I.Alekseev A. I. Criminology .: Course lecture. M .: 1999, - P. 115.
}

account that if criminological preventive measures affect the conditions and objective and subjective causes of crime, coercive legal measures affect only subjective causes and conditions, factors that affect the individual ${ }^{3}$.

Regardless of the reasoning on which the court is based, the specific circumstances of the case and the identity of the defendant must be carefully considered, as this is a necessary condition for the convict to be psychologically influenced. However, this should not allow for a breach of the close link between the intent to prevent the commission of new crimes, both by convicts and by other persons intended to be punished.

The law, which establishes strict criminal liability for sexual assault, is of great educational importance. Therefore, it would be wrong to equate the role of criminal law in the fight against sexual violence only to a means of punishing perpetrators. When criminal law applies to any person, including those who have committed sexual violence, its importance is not limited to the role of the "fortress" that protects the individual and public order. Recognizing this or that action as criminal and punishable, it inculcates in the citizens a negative attitude towards these actions, involving them in the fight against these actions. This is why advocacy of the law is so important. In particular, legislation establishing liability for sexual assault should not only be communicated to young people, but should also be comprehensively explained.

In such conversations, it is necessary not only to inform about the penalties for this crime,

${ }^{3}$ Criminology: General frequency. SPb., 1992. - P. 141. 
but also to expose its social danger, immorality, inhumanity, to educate young people in the spirit of hatred for disorderly sex and violence in general. Finally, the educational effect on the convict during the execution of the sentence, raising his level of consciousness and knowledge also nurtures in man a more stable basis in the field of sex, because sex education is inseparable from general education.

In addition, in determining measures to prevent crimes against the sexual integrity and sexual freedom of minors, special attention should be paid, first of all, to the causes and conditions of these crimes and the elimination of socially dangerous consequences resulting from the crime.

In order to prevent the criminal behavior of persons who violate the sexual integrity of minors, it is necessary to identify the following characteristics of the offender:

- Whether this person has previously committed a crime or not;

- The presence of mental anomaly in the person;

- Determination of the place of employment of the person or the range of persons with whom he is in contact. For example, individuals trying to infringe on the sexual integrity of young children are often employed in children's institutions;
- Committing sexual offences during childhood or adolescence due to sexual interest or illness;

- Symptoms of hysterical illness when communication with the members of the opposite sex;

- The commission of immoral and sexual acts that do not give rise to criminal liability;

- Suicide attempts that were committed as a result of sexual failures;

- Presence of unmotivated acts committed by a person using sexual violence ${ }^{4}$.

Measures for the prevention of crimes against the sexual integrity and sexual freedom of minors can be divided into general, or social preventive measures, and special (criminological) preventive measures.

The general prevention of this type of crime is comprehensive and is carried out by the creation of conditions for the positive development of society, the development of existing social, economic, political and other institutions, the elimination of incidents and disparities that lead to crimes against the sexual integrity of minors, reducing the harmful effects of such conditions. General preventive measures can also be referred to as indirect prevention. In other words, crime is prevented by ensuring general well-being in the society, development of all social relations in the society, elimination of poverty, unemployment, child neglect, difficult living conditions, freedom of society, elimination of

\footnotetext{
4 Yu.M. Antonyan, A.A. Tkachenko, B.V. Shostakovich. Criminal sexology. Under. ed. Antonyan Yu.M. - M .: Spark, 1999 .-P. 397-398.
} 
immorality and corruption organized by individuals and groups using democracy.

Among the social measures for the prevention of sexual assault on minors, it is important to ensure the spiritual growth of members of society, the development of their spiritual, cultural, moral and legal consciousness. Because committing sexual crimes shows how low the moral and cultural level of the perpetrator is, his level of immorality, unconsciousness.

The family, which is the most important institution in society, plays a special role in the prevention of crimes against the sexual integrity and sexual freedom of minors. In particular, the high incidence of this type of crime within the family means that important measures need to be developed in this area. This includes the registration of unhealthy families and the establishment of constant public control over them, the identification of morally unhealthy parents with various behavioral disorders, upbringing them through public influence, and, if upbringing is not possible, the behavior of parents whose disorders may adversely affect their minor children should be avoided. In addition, the implementation of measures aimed at improving the leisure time of families, the implementation of measures to eliminate child neglect will also have a positive effect.

In our view, the fact that the main part of crimes against the sexual integrity and sexual freedom of minors requires stemming from the victimization of victims, the development and

5 A.V. Frank. Victimology and victimization. Dushanbe, 1972 .-- P. 25.

6 S.S.Niyozova. Criminal law and criminological aspects of crimes against morality: Monograph. // implementation of victimological measures against them. At the same time, the focus should be on the victimization of juvenile victims and the sexual, physical and mental harm inflicted on them as a result of the crime. Therefore, as a preventative measure against the crimes of sexual integrity and sexual freedom of minors, the idea that "In addition to reducing the number of people prone to crime, special attention should also be paid to reducing the number of victims of such criminal aggression"5 should not be overlooked. To do this, it is important, first of all, to properly bring up minors ${ }^{6}$.

But today we pay less attention to the field of sex life, which is one of the most important areas of life, and we do not pay attention to the sexual education of young people. As a result, young people face a problem as soon as they encounter the first relationship in this area, and in most cases it ends up with a violation of the sexual integrity of minors. To prevent this, it is advisable to organize sex education classes in the family and in educational institutions in conjunction with medical staff .

The violence in a family also leads to the emergence of crimes against the sexual integrity and freedom of minors. According to the results of research, female persons are victims in $75.8 \%$ of cases of domestic violence. For example, women become victims in $70 \%$ of cases of threats of murder or causing serious harm. As the study conducted by scientists has shown, most often victims of pressure in the family are the wives (cohabitants) (48.1\%), children (15.6\%), as well as the parents (14.2\%)

Responsible editor: Yu.f.d., professor G.Z.Tulaganova. - P. 52. 
of the culprit. In addition, these crimes are committed against spouses (cohabitants) (5.1\%), sisters and brothers (3.8\%), as well as other family members or relatives of the perpetrators - grandfathers, grandmothers, grandchildren, uncles, aunts, nephews, parents and siblings of husbands (cohabitants) and others (13.2\%). On the whole, members of the female family own an overstated degree of victimization, the proportion of which among all the victims of domestic violence crimes learned is $75.8 \%$. Analysis of domestic violence offenses was most frequently reported between $6 \mathrm{pm}$ and $12 \mathrm{pm}$. During these 6 hours, 46.5 percent of total crimes were committed. Minimum violence time is $4.1 \%$ between $06: 00$ am and 9:00 am. Therefore, it is important to monitor the environment and the situation in the family in the late evening, effectively utilizing the capabilities of the wider community and community members ${ }^{7}$.

The most common of the factors determining the criminological characterization of the victim in aggression against the sexual integrity and liberty of minors are the consumption of alcohol by the juvenile in conjunction with the aggressor, unethical behavior of a minor, seductive clothes (mini skirts, etc.), turning conversations into sexual topics, seductive jokes, anecdotes and more can be shown.

According to the materials of the criminal case study, $28 \%$ of the juvenile victims smoked, $34 \%$ smoked and drank alcohol, $18 \%$ used drugs, and $20 \%$ had tattoos on the victim's body. Also, in this type of crime - in 55\% of cases the victim was intoxicated, and in 30\% of cases the victim drank alcohol with the accused.

${ }^{7}$ S.S.Niyozova. Prevention of Crime in the Family and the Role of Victimology in the Republic of Uzbekistan. International Journal of Advanced
The vast majority of crimes $(57 \%$ in a closed room (including an apartment or other living room), $12 \%$ in stairwells, basements, elevators, stairs or stairwells in home entrances, cars); $20 \%$ on the street, alley or park; $6 \%$ occurred in public places. In $5 \%$ of cases, the crime scene could not be identified.

We also see that juvenile delinquency is widespread ( $27 \%$ of victims were raped, $13 \%$ were assaulted), and the sexual and marital status of the victims was psychologically affected. All of these situations serve to trigger and exacerbate the criminogenic situation as a victim behavior.

We study such victim behavior dividing it into three groups:

1. Behavior that incites to commit a crime. In such a case, the victim engages in actions that encourage individuals who are less familiar with his or her behavior or who are not at all familiar to have sex in an unfamiliar place (the defendant's home or elsewhere). Victims of this behavior make up $10-15 \%$ of victims of sexual crimes (1/3 of the research of German scientists).

2. The victim had a behavior that provided an objective opportunity to have sex, even it was not provacative. For example, a woman may walk alone in the evening when there is no one and there is a risk of aggression, and so on. Such behaviors accounts for $35-40 \%$ of victims.

3. Neutral behavior. That is, a person creates conditions for him without realizing that he will become a victim of crime through his behavior. This category of people includes,

Science and Technology Vol. 29, No.3, (2020). p. 3960 - 3969. 
first of all, young children and the elderly, who make up $45-60 \%$ of the victims.

According to the results of the research, the study of the criminogenic characteristics of victims of aggression against the life, health, sexual integrity and freedom of minors requires their classification according to age. In our opinion, the following classification is appropriate in this regard: Criminological description of juvenile victims under 14 years of age and 14 to 18 years of age.

Without a doubt, the criminogenicity of juvenile victims under 14 years of age is different from that of 14-18 years of age. Juveniles (young children) in the first group know that they have been abused and tortured. But they may not be able to explain it clearly. And if the victims are school-age children, they are often embarrassed to tell adults about the bad behavior that has been committed against them. Children between the ages of 12 and 14 are unaware that sexual acts committed against them are a contamination of their physical and spiritual (moral) purity. In this regard, E.B Melnikova rightly noted that the genetic, demographic and individual mental qualities of today's children and adolescents lead primarily to their change depending on certain conditions.

The second group, the minors between the ages of 14 and 18, are sometimes prone to prostitution. Because it satisfies the sexual interest that is aroused in them. This group requires the study of victims in two more categories: those aged 14 to 16 years and those aged 16 to 18 years.
The reason we divide the victims of these crimes into such categories is that crimes against the sexual integrity of minors are directed against persons under the age of 16 . At the same time, minors between the ages of 16 and 18 can only be victims of rape, sexual exploitation and prostitution.

This is because such individuals, unlike victims under the age of 16 , understand the negative consequences of the actions that may be taken against them. Thus, the following can be cited as factors contributing to the latency of crimes against the health, sexual integrity and liberty of minors:

1. Insufficient life experience and low rate of legal consciousness of the victim;

2. Cowardice, not to be ashamed, as well as to avoid the "talk" of neighbours in the neighborhood;

3. Fear that the minor's future marriage will be disrupted;

4. Threats as a revenge by the assailant and his close relatives or friends;

5. Failure to notify law enforcement agencies in time, etc.

For example, the culprit Sh, starting from mid2017 to the end of 2018, steadily raped his stepdaughter A, and sexually abused her in an unnatural way. It was only when his wife realized this and reported it to law enforcement that his crime was exposed. Till that time, A. did not tell anyone about his stepfather's behavior.

One of the criminological features of juveniles who are victims of this type of crime is explained by the fact that they try not only to inform their parents or other elderly relatives, but also to keep their relationship as secret as 
possible. Consequently, sexual assault causes serious damage to the health and personality of minors. It is not a matter of protecting the sexual integrity of the child, but of the individual's right to physical and socially healthy development.

The activities of the subjects are also important in the conduct of sexual education and the prevention of neglect of minors.

Appraisal concepts in criminal law is a necessary circumstance, since no alternative, solutions that are more effective have been found ${ }^{8}$.

Indeed, in accordance with paragraph 2 of the Regulation "On interdepartmental commissions on juvenile affairs" approved by the President of the Republic of Uzbekistan on March 14, 2017 No PP-2833 “On measures to further improve the system of crime prevention and fight against crime", republican commissions, as well as regional commissions, district (city) commissions are the bodies carrying out their activities on a public basis, which are:

Prevention of neglect, uncontrollability, delinquency and other antisocial behavior among minors, identification and elimination of their causes and conditions;

ensuring the protection of the rights, freedoms and legitimate interests of minors;

\footnotetext{
${ }^{8} \mathrm{Kh} \mathrm{K}$. F. Extreme cruelty is as the way of committing crime of murder: theoretical-practical problems and their solutions //European Journal of Research. https://journalofresearch. info/-Vienna, Austria. 2019. - T. 4. - №. 10. - C. 8-11.
}

for the purpose of social and pedagogical rehabilitation of minors in socially dangerous situations.

In the document, it is said that territorial commissions are accountable to higher commissions in their activities, keep them informed and report on their activities on a quarterly basis ${ }^{9}$.

Article 9 of the Law of the Republic of Uzbekistan adopted in September 8, 2017 “On protection of children from information harmful to their health" also defines the activities of the republican interdepartmental commissions on juvenile affairs.

Our national legislation pays special attention to the rights and interests of children, the prevention of juvenile delinquency, as well as their protection. The attention of all citizens and officials is focused on the comprehensive development of young people. Particular attention is paid to the development of young people, both physically and spiritually healthy, their happiness, a prosperous future, the upbringing of a generation that is second to none in the world.

In addition, the Law of the Republic of Uzbekistan adopted in September 29, 2010 "On the prevention of uncontrollability and delinquency among minors" is directed at the solutions for such issues as clear determination of system bodies and institutions dealing with these issues, regulation of their tasks, directions and functions, as well as the grounds and procedure for the organization of

9 Regulation of the President of the Republic of Uzbekistan dated March 14, 2017 "On interdepartmental commissions on juvenile affairs". Collection of legislation of the Republic of Uzbekistan. - March 27, 2017. - №12., Article 184. 
individual preventive work with minors and families requiring special attention, the procedure and grounds for placement of minors in specialized educational institutions and centers of social and legal assistance, the legal status of minors in socially dangerous situations; legal and pedagogical rehabilitation.

It should be noted that in some cases, sexual offenses committed by minors necessitate constant monitoring. It is especially important to help young people to organize their free time properly, and to control them during this period. According to criminologists, crimes of rape and violence against minors are more common in the summer. Because they are on summer vacation at this time and are free from pedagogical supervision.

It is also important to make effective use of the capacity of the workforce in the prevention of sexual crimes. Because the person spends most of their time with the work team. Creating an environment of hatred for various impurities in the work community has a positive effect on an individual's proneness to crime $^{10}$.

The following measures also play a positive role in the overall prevention of crimes against the sexual integrity and sexual freedom of minors: establishing social control over individuals who are capable of committing sexual offenses, taking into account their behavior and the description given by the public; establishing administrative control over

${ }^{10}$ Yu.Musaev. Juveniles and recidivism // J. Life and law. - 2001. - №4. - P. 55-56.

${ }^{11}$ Khudaykulov F. K. Force And Threat Of Violence Are As The Ways Of Commission Of Rape: National individuals previously convicted of rape or other sexual offenses; taking operative measures related to the notification of persons, preventing the commission of the crime of rape; taking special measures to rehabilitate and improve the behavior of persons convicted of sexual offenses, and to carry out legal, psychological and medical measures against persons serving sentences in penitentiaries; introduction of postprophylactic prevention of persons who have committed rape and other sexual crimes related to administrative control, as well as through the use of medical measures; introduction and practical application of victimological prophylaxis.

Rape and other sexual assaultsare commonly committed in industrialized countries, and are becoming more common throughout the world. Insome countries' jurisdictions, malefemale rape is the only form of rape counted in the statistics. many countries may not define forced and threat of violence sex on a spouse as "rape". But those criminal acts are considered a crimein criminal law which belongs to those countries. Although rape is expressed the same in the legislation of different countries, it differs in some. rape as a crime is three the ways of commission crime ${ }^{11}$.

The reasons for the selection of compositions are the following signs: time, situation, mental state of the mother. The first two are related to the objective side of the crime while the third to the subject of the crime $^{12}$.

And Foreign Experience //Psychology and Education Journal. - 2021. - T. 58. - №. 1. - C. 1123-1132.

12 Feruzbek K. OFFENCE OF INFANTICIDE: NATIONAL AND FOREIGN EXPERIENCES //Review of law sciences. - 2020. - №. 4. 
The use of measures against socially negative conditions, such as the prevention of alcoholism, drug addiction, prostitution etc. is also necessary in the prevention of sexual assault of minors. Because the analysis of forensic practice shows that sex crimes are often committed in a state of intoxication or in conjunction with prostitution. While the general prevention of crimes against the sexual integrity and sexual freedom of minors is carried out through the development of the criminal capacity of society and all its institutions, special prevention by the competent authorities to reduce, attenuate, eliminate criminogenic factors of crimes against the sexual integrity and sexual freedom of minors consists of a set of measures aimed at preventing the continuation of criminal activity of persons who may or may not have committed a new crime, and for a specific type and specific prevention.

The General Directorate for the Prevention of Offenses of the Ministry of Internal Affairs of the Republic of Uzbekistan (hereinafter - the Main Directorate) is a structural subdivision of the Ministry of Internal Affairs (hereinafter the Ministry of Internal Affairs) of the Republic of Uzbekistan in the system of internal affairs bodies, which provides, in accordance with the legislation, methodological guidance and coordination of the activities of the units for the prevention of offenses of internal organs affairs. It is also worth noting that in order to improve the structure of the Main Directorate, as well as improve the quality of work of subjects of prevention and crime prevention, the Decree of the President of the Republic of Uzbekistan dated April 10, 2017 "On measures to radically increase the efficiency of the activities of the internal affairs bodies, strengthen their responsibility for ensuring public order, reliable protection of the rights, freedoms and legitimate interests of citizens" In particular, the following directions were set to improve the prevention and prevention of crimes:

the introduction of a qualitatively new routine for organizing the work of republican, medium and lower-level crime prevention units, taking into account the precise definition and separation of their main tasks, functions and responsibilities, preventing the assignment of inspectors for the prevention of functions uncharacteristic of them;

the organization of preventive work in narrow cooperation with the population, citizens' selfgovernment bodies and other civil society institutions, aimed, first of all, at providing early warning of crimes, raising the legal culture in the community, instilling respect for citizens in the law and intolerance to any manifestations of violations of the law;

development of a system of work with minors and youth aimed at educating them in the spirit of love for the motherland, patriotism, respect for national and universal values, protecting the younger generation from the ideas of terrorism, religious extremism, violence and cruelty;

It is also worth noting that the improvement of crime prevention and the activities of prevention entities were indicated as one of the directions by the President of the Republic 
of Uzbekistan in the Strategy for the Further Development of the Republic of Uzbekistan ${ }^{13}$.

One of the important institutions for crime prevention in this area is international organizations. WHO, Sexuality and Family Planning Unit, International Planned Parenthood, FIGIJ, international organizations such as the Federation of Children and Adolescent Gynecologists, Magdalene rescue and rehabilitation ${ }^{14}$. Therefore, the state bodies tasked with the prevention of crime in our country should work in direct cooperation with these international organizations to combat crimes that infringe on the sexual integrity and freedom of minors.

The most important specially authorized bodies in the field of crime prevention are the organs of internal affairs, which play an important role in the prevention of crimes against the sexual integrity of minors. Because such organs may have broader experience and special systems in the prevention of crimes. The measures taken by the law enforcement agencies to prevent crimes against the sexual integrity and liberty of minors should be carried out in two directions. The first is the usual rapid search operations, which include:

Special measures to prepare for or determine whether such crimes have been committed;

13 S.S.Niyozova. Prevention of Crime in the Family and the Role of Victimology in the Republic of Uzbekistan. International Journal of Advanced Science and Technology Vol. 29, No.3, (2020). p. $3960-3969$.

${ }^{14}$ Sexual abuse in adolescents. A handbook for cadets. Edited by Professor Yu.A. Gurkin. - St. Petersburg: PPMI, 1997. - P. 21.
Identifying individuals who are prone or capable of committing sexual offenses based on their behavior and characteristics;

Reporting by analyzing the abovementioned circumstances and individuals, and forecasting crimes against sexual integrity in the future etc..

A selfish goal, that is, the desire of the perpetrator to obtain material benefits by illegal means. It is expressed in the desire to have the actual opportunity to illegally own, use and dispose of someone else's property as his own, that is, personally consume or use it in another way, sell, donate, lend to other persons, as payment for debt or services rendered ${ }^{15}$.

That is, the first area is the collection and analysis of information on crimes against sexual integrity and liberty, and the preventive measures outlined above. The second direction is the development and implementation of preventive measures, which will be carried out in the following areas:

To take measures to inform the population about the crime and its near-term forecast by the press service of the organs of internal affairs, its vigilant implementation, as well as the formation of protective immunity against persons who may be subjected to aggression;

\footnotetext{
${ }^{15}$ Khudaykulov F. K. et al. Legal Analysis Of The Theft And Its Objective Side In Uzbekistan And India: National And Foreign Experience //The American Journal of Political Science Law and Criminology. 2021. - T. 3. - №. 04. - C. 79-87.
} 
establishing permanent control over individuals who are prone or capable of committing registered sexual offenses;

Taking concrete measures to prepare for and prevent the commission of crimes against sexual integrity;

Taking measures to prevent recidivism of crimes against sexual integrity. The abovementioned preventive measures should, of course, be of a rapid nature at the same time ${ }^{16}$.

Also, clear identification of the crime scene by the organs of internal affairs is an effective tool for crime prevention. For example, one of the preventive measures is to compile a list of crimes committed in summer resorts, mark them in the "Road Maps" and strengthen control by special units of the organs of internal affairs in those areas. It is also possible to prevent this type of crime by tightening controls during school holidays - January, March, May and summer.

Prosecution agencies also play a central role in preventing crimes that infringe on the sexual integrity and liberty of minors. Because the prosecutor's office coordinates the activities of law enforcement agencies in the fight against crime $^{17}$.

Based on the above, the main tasks of the prosecutor's office in the prevention of crimes against the sexual integrity and sexual freedom of minors are:

${ }^{16}$ S.S. Krashennikov. Prevention of mercenary crimes committed in restaurant cars. Tutorial. - M., 1995 .-P. 44.

${ }^{17}$ Камалова, Д.Г., Рахимжонова, Н.Р., 2020. Жиноятларни таснифлаш тизими ва мезонларини такомиллаштиришнинг айрим масалалари.
Develops, approves and implements programs for the prevention of crimes against the sexual integrity and liberty of minors;

Coordinates and supervises the activities of state bodies charged with the prevention of crimes against the sexual integrity and sexual freedom of minors;

Participates in legislative activities on the prevention of crimes against the sexual integrity and liberty of minors;

Participates in legal advocacy activities aimed at preventing juvenile delinquency and raising their legal awareness and culture in this area, as well as strengthening the rule of law;

Cooperates with other state bodies, public organizations on the prevention of crimes against the sexual integrity and liberty of minors.

The role of the judiciary in eliminating crimes against the sexual integrity and sexual freedom of minors is also significant. Its civil registry offices, which are part of its system, can prevent sexual offenses with a person under the age of sixteen that may occur through an informal marriage ${ }^{18}$. To this end, the civil registry offices should conduct legal advocacy work on family and marriage issues among the population, not only by refusing to register the marriage when one of the parties to the marriage is under the age of sixteen, but also by they must be warned that they will be prosecuted if they have sexual intercourse.

«Хукуқий тадқиқотлар» электрон журнали, 2(SPECIAL 3).

${ }^{18}$ NR Rakhimjonova, Classification System of

Crimes in Criminal Code of the Republic of

Uzbekistan, Psychology and Education Journal 58

(1), 1094-1101 
In order for the above-mentioned special authorities to take regular measures to prevent this type of crime: first, such measures must be provided in an organized manner; second, it should be applied only by the competent state authorities; third, such authorities must have complete and reliable information in a timely manner; fourth, preventive measures should come into force and be enforced through legal norms. In addition to special government agencies, citizens should be actively involved in the prevention of crimes against sexual integrity and sexual freedom by informing law enforcement agencies that they are being prepared or committed.

In addition to the above, a special institution, a special psychiatric clinic, should be established in the Republic of Uzbekistan for the prevention of crimes against the sexual integrity of minors ${ }^{19}$. The psychiatric clinic maintains mentally ill maniacs who violate the sexual integrity of young children and juveniles, and specialists study their individual (brain, psychiatric) changes and characteristics, and closely assists in the prevention of new crimes committed by them.

In conclusion, in order to effectively prevent crimes against the sexual integrity and liberty of minors, it is necessary to simultaneously identify the circumstances that create the conditions for the crime, taking into account the identity of the offender, the victim's behavior, age, family and personal life, time and place of the crime.

\section{REFERENCES}

1. Q.R.Abdurasulova, O.Zokirova. Criminology. Training manual. - T .: TDYul, 2003. - P. 28-29.

2. A.I.Alekseev A. I. Criminology .: Course lecture. - M .: 1999, - P. 115.

3. Criminology: General frequency. SPb., 1992. - P. 141.

4. Yu.M. Antonyan, A.A. Tkachenko, B.V. Shostakovich. Criminal sexology. Under. ed. Antonyan Yu.M. - M .: Spark, 1999 .-P. 397-398.

5. A.V. Frank. Victimology and victimization. Dushanbe, 1972 .-- P. 25.

6. S.S.Niyozova. Criminal law and criminological aspects of crimes against morality: Monograph. // Responsible editor: Yu.f.d., professor G.Z.Tulaganova. - P. 52.

7. S.S.Niyozova. Prevention of Crime in the Family and the Role of Victimology in the Republic of Uzbekistan. International Journal of Advanced Science and Technology Vol. 29, No.3, (2020). p. 3960 3969.

8. Kh K. F. Extreme cruelty is as the way of committing crime of murder: theoreticalpractical problems and their solutions //European Journal of Research. https://journalofresearch. info/-Vienna, Austria. - 2019. - T. 4. - №. 10. - C. 8-11.

9. Regulation of the President of the Republic of Uzbekistan dated March 14, 2017 "On interdepartmental commissions on juvenile affairs". Collection of legislation of the Republic of Uzbekistan. March 27, 2017. - №12., Article 184.

\footnotetext{
${ }^{19}$ N.Raximjonova, 2020. Jinoyatlar tasnifining
} farqlanishi. "Odillik me'zoni”" Vol. 11, pp. 36-39 
10. Yu.Musaev. Juveniles and recidivism // J. Life and law. - 2001. - №4 - - P. 55-56.

11. Khudaykulov F. K. Force And Threat Of Violence Are As The Ways Of Commission Of Rape: National And Foreign Experience //Psychology and Education Journal. 2021. - T. 58. - №. 1. - C. 1123-1132.

12. Feruzbek K. OFFENCE OF INFANTICIDE: NATIONAL AND FOREIGN EXPERIENCES //Review of law sciences. - 2020. - №. 4.

13. S.S.Niyozova. Prevention of Crime in the Family and the Role of Victimology in the Republic of Uzbekistan. International Journal of Advanced Science and Technology Vol. 29, No.3, (2020). p. $3960-$ 3969.

14. Sexual abuse in adolescents. A handbook for cadets. Edited by Professor Yu.A. Gurkin. - St. Petersburg: PPMI, 1997. - P. 21.

15. Khudaykulov F. K. et al. Legal Analysis Of The Theft And Its Objective Side In Uzbekistan And India: National And Foreign Experience //The American Journal of Political Science Law and Criminology. - 2021. - T. 3. - №. 04. - C. 7987.

16. S.S. Krashennikov. Prevention of mercenary crimes committed in restaurant cars. Tutorial. - M., 1995 --- P. 44.

17. Камалова, А.Г., Рахимжонова, Н.Р., 2020. Жиноятларни таснифлаш тизими ва мезонларини такомиллаштиришнинг айрим масалалари. «Хуқуқий тадқиқотлар» электрон журнали, 2(SPECIAL 3).

18. NR Rakhimjonova, Classification System of Crimes in Criminal Code of the Republic of Uzbekistan, Psychology and Education Journal 58 (1), 1094-1101
19. N.Raximjonova, $2020 . \quad J i n o y a t l a r$ tasnifining farqlanishi. "Odillik me'zoni" Vol. 11, pp. 36-39 